\title{
Cellular characterization of pituitary adenoma cell line (AtT20 cell) transfected with insulin, glucose transporter type 2 (GLUT2) and glucokinase genes: Insulin secretion in response to physiological concentrations of glucose
}

\author{
S. Motoyoshi, T. Shirotani, E. Araki, K. Sakai, K. Kaneko, H. Motoshima, K. Yoshizato, A. Shirakami, H. Kishikawa, \\ M. Shichiri \\ Department of Metabolic Medicine, Kumamoto University School of Medicine, Kumamoto, Japan
}

\begin{abstract}
Summary We investigated the mechanisms of insulin secretion by transfecting into a pituitary adenoma cell line (AtT20) a combination of genes encoding human insulin (HI), glucose transporter type 2 (GLUT2) and glucokinase (GK), followed by studying the characteristics of these cells. In static incubation, a cell line transfected with insulin gene alone (AtT20HI) secreted mature human insulin but this was not in a glucose-dependent manner. Other cell lines transfected with insulin and GLUT2 genes (AtT20HI-GLUT2-3) or with insulin and GK genes (AtT20HI-GK-1) secreted insulin in response to glucose concentrations of only less than $1 \mathrm{mmol} / \mathrm{l}$. In contrast, cell lines transfected with insulin, GLUT2 and GK genes (AtT20HI-GLUT2-GK-6, AtT20HI-GLUT2GK-7 and AtT20HI-GLUT2-GK-10) showed a glucose-dependent insulin secretion up to $25 \mathrm{mmol} / \mathrm{l} \mathrm{glu}$ cose. Glucose utilization and oxidation were increased in AtT20HI-GLUT2-GK cell lines but not in AtT20HI, AtT20HI-GLUT2-3 and AtT20HIGK-1 cells at physiological glucose concentrations, compared with AtT20 cells. Diazoxide, nifedipine and 2-deoxy glucose suppressed $(p<0.05)$ glucose
\end{abstract}

stimulated insulin secretion in AtT20HI-GLUT2GK-6 cells. Glibenclamide, $\mathrm{KCl}$ or corticotropin releasing factor $(\mathrm{CRF})$ stimulated $(p<0.05)$ insulin secretion both in AtT20HI and AtT20HI-GLUT2GK-6 cells. Insulin secretion stimulated by glibenclamide, $\mathrm{KCl}$ or $\mathrm{CRF}$ was further enhanced by the addition of $25 \mathrm{mmol} / \mathrm{l}$ glucose in AtT20HI-GLUT2-GK-6 cells but not in AtT20HI cells. In perifusion experiments, a stepwise increase in glucose concentration from 5 to $25 \mathrm{mmol} / \mathrm{l}$ stimulated insulin secretion in AtT20HI-GLUT2-GK cell lines but the response lacked a clear first phase of insulin secretion. Our results suggest that both GLUT2 and glucokinase are necessary for the glucose stimulated insulin secretion in at least rodent cell lines, and that other element(s) are necessary for a biphasic insulin secretion typically observed in beta cells. [Diabetologia (1998) 41: 14921501]

Keywords AtT20 Cell, insulin secretion, human insulin gene, glucose metabolism, glucose transporter type 2 (GLUT2), glucokinase
Received: 9 February 1998 and in revised form: 19 May 1998

Corresponding author: H. Kishikawa, M.D., Ph. D., Department of Metabolic Medicine, Kumamoto University School of Medicine, 1-1-1, Honjo, Kumamoto, 860-8556, Japan Abbreviations: BSA, Bovine serum albumin; CRF, corticotropin releasing factor; DTT, dithiothreitol; 2-DG, 2-deoxy glucose; DMEM, Dulbecco's modified Eagle's medium; FBS, fetal bovine serum; GK, glucokinase; GLUT, glucose transporter; HBSS, Hanks' balanced salt solution; HEPES, N-(2-hydroxyethyl)-piperazine- $\mathrm{N}^{\prime}$-2-ethanesulphonic acid; PCR, polymerase chain reaction; SDS, sodium dodecyl sulphate; IRI, immunoreactive insulin.
Pancreatic beta cells secrete insulin in response to glucose and other energetic substrates such as amino acids, fatty acids and ketone bodies but this secretion is selectively impaired in patients with Type II (noninsulin dependent) diabetes mellitus [1-3]. Therefore, to understand the pathogenesis of diabetes and the treatment of these patients it is important to elucidate the mechanisms of such secretion.

There is convincing evidence that high glucose concentration stimulates insulin secretion in beta cells by increasing the rate of glucose metabolism. This leads to the generation of intracellular messen- 
gers through ATP-sensitive $\mathrm{K}^{+}$and voltage-dependent $\mathrm{Ca}^{2+}$ channels that trigger exocytosis. In this process, a high-Km ( $>15 \mathrm{mmol} / \mathrm{l})$ glucose transporter (GLUT)2 [4, 5] and high-Km (7-11 mmol/l) glucose phosphorylating enzyme, glucokinase [5-7] have key roles in the regulation of glucose metabolic flux rate through glycolysis in beta cells and thereby generate the necessary signals for glucose stimulated insulin secretion [5-8]. Glucose is, however, also known to control insulin secretion independent of changes in ATP-sensitive $\mathrm{K}^{+}$channel activity $[9,10]$ or intracellular $\mathrm{Ca}^{2+}$ concentration [10].

Results of human and animal studies indicated that alterations of GLUT2 or glucokinase in beta cells or both are of pathogenic importance in impaired signal recognition for insulin secretion and possibly result in Type II diabetes mellitus [11-15]. The pathogenic importance of GLUT2 in humans is, however, still under investigation. Several reports have suggested that the expression of GLUT2 mRNA and protein in human beta cells is less than in rodents' beta cells $[16,17]$.

Several research centers have concentrated on molecular engineering of an "artificial beta cell" using non-beta cells. The anterior pituitary cell line, AtT20, is a candidate for such studies because it can process proinsulin and secrete mature insulin by stable transfection with the insulin gene [18-23]. Only one model of an "artificial beta cell" could exhibit glucose stimulated insulin secretion by additional transfection with GLUT2 cDNA [20,21], but the glucose concentration which stimulated insulin secretion ranged between 10 and $50 \mu \mathrm{mol} / \mathrm{l}$, which was lower than that observed in beta cells [20-22]. We speculated, on the basis of results of studies that showed an extremely low activity of glucokinase in AtT20 cells relative to that in pancreatic beta cells [24, 25], that these low concentrations of glucose were due to differences in glucokinase expression between the two cell types.

We investigated the effects of overexpression of GLUT2 and glucokinase on insulin secretion in AtT20 cells stably transfected with the human insulin gene. Furthermore, to characterize insulin secretion in the newly constructed cells, we evaluated the glucose metabolism rate and the effects of ATP-sensitive $\mathrm{K}^{+}$channel opener, $\mathrm{Ca}^{2+}$ channel blocker, 2-deoxy glucose (2-DG), sulphonylurea, $\mathrm{KCl}$ and corticotropin releasing factor $(\mathrm{CRF})$.

\section{Materials and methods}

Materials. Geneticin (G418), L-Histidinol-2HCl, N-(2-hydroxyethyl)-piperazine- $\mathrm{N}^{\prime}$-2-ethanesulphonic acid (HEPES), 2-amino-2-(hydroxymethyl)-1, 3-propanediol (Tris), DNase (RNase-free), bovine serum albumin (BSA), dithiothreitol (DTT), glucose-6-phosphate dehydrogenase, 2-DG, glibenclamide, diazoxide, nifedipine, corticotropin releasing factor
(CRF) and hydroxy hyamine were purchased from Sigma (St. Louis, Mo., USA). $\left[\alpha_{-}{ }^{32} \mathrm{P}\right] \mathrm{dCTP},\left[{ }^{125} \mathrm{I}\right]$ Protein A, 3-O-methyl$\mathrm{D}-\left[{ }^{3} \mathrm{H}\right]$ glucose, D- $\left[5-{ }^{3} \mathrm{H}\right]$ glucose, $\left[{ }^{3} \mathrm{H}\right]$ water and $\mathrm{D}-\left[\mathrm{U}-{ }^{14} \mathrm{C}\right]$ glucose were from NEN-Dupont (Wilmington, Del., USA). Fetal bovine serum (FBS) was from Intergen (N. Y., USA). Dulbecco's modified Eagle's medium (DMEM) was from Gibco (Grand Island, N. Y., USA). Lipofectin reagent was from BRL (Gaithersburg, Md., USA). Biosilon was from Nunc (Kamstrup, Denmark). Sep-Pak C18 cartridge was from Nihon Millipore (Tokyo, Japan). Ultrasphere IP $5 \mu \mathrm{m}$ column was from Beckman Instruments Inc. (Fullerton, Calif., USA). Rabbit anti Rat GLUT2 was from Transformation Research Inc. (Framingham, Mass., USA). Goat anti-glucokinase was from Santa Cruz Biotechnology, Inc. (Santa Cruz, Calif., USA). All restriction enzymes, Ampli Taq DNA polymerase, nitrocellulose membrane, RNase inhibitor, Gene clean kit, Sequenase version 2.0 DNA sequencing kit and Takara RNA LA PCR Kit (AMV) were from Takara Shuzo (Kyoto, Japan). Micro BCA protein assay system was from Pierce (Rockford, Ill., USA). Ab Bead Insulin Eiken Radioimmunoassay Kit was from Eiken Chemical Co. (Tokyo, Japan). AtT20 D-16v/F2 cells (CRL-1795) were purchased from American Type Culture Collection (ATCC) (Rockville, Md., USA). MIN6 cells and pAc3 plasmid were kind gifts from Dr. Miyazaki (Osaka University School of Medicine, Japan).

Cell culture. AtT20 cell lines were grown in DMEM with $25 \mathrm{mmol} / \mathrm{l}$ glucose and $10 \%$ FBS. MIN6 cells [26] were grown in DMEM with $25 \mathrm{mmol} / \mathrm{l}$ glucose and $20 \%$ FBS under $5 \%$ $\mathrm{CO}_{2}-95 \%$ air at $37^{\circ} \mathrm{C}$.

Plasmid construction. A $12 \mathrm{~kb}$ pair fragment containing the $5^{\prime}$ flanking region of human insulin gene was cloned from a human genomic library by a plaque hybridization method using a ${ }^{32} \mathrm{P}$-labelled polymerase chain reaction (PCR) product derived from human genomic DNA with primers designed from the human insulin gene [27] (sense primer -24 to 6 and antisense primer 237 to 266 ). A $2.6 \mathrm{~kb}$ fragment of the human insulin gene was isolated by NcoI and XhoI digestion, and EcoRI linkers were ligated at both ends of the fragment. The fragment was digested with EcoRI and inserted correctly into the EcoRI site of pAc3 plasmid [28], which contained a chicken $\beta$-actin promoter (pAc3-HI).

GLUT2 cDNA and islet glucokinase cDNA of rats were amplified by reverse transcription-polymerase chain reaction (RT-PCR). Total RNA ( $3 \mu \mathrm{g})$ extracted from the rat liver or islets was reverse transcribed into cDNA using Takara RNA LA PCR Kit (AMV), and the cDNA was amplified using a thermal cycle programmer (Model 300, Astec, Fukuoka, Japan). The primers used for PCR reactions were designed from the sequences of the rat liver GLUT2 cDNA [4] (sense primer -24 to -5 and antisense primer 1821 to 1840 ), and rat islet glucokinase cDNA [25, 29] (sense primer -28 to -9 and antisense primer 1808 to 1827). After amplification, the PCR products were subjected to $1 \%$ agarose gel electrophoresis and extracted using a Gene Clean kit. Both ends of the purified fragments were ligated with EcoRI linkers and subcloned into the EcoRI site of pUC19 plasmid, and sequenced with a Sequenase version 2.0 DNA sequencing kit and $\left[\alpha^{32} \mathrm{P}\right] \mathrm{dCTP}$. The rat GLUT2 cDNA fragment or islet glucokinase cDNA fragment was digested with EcoRI and inserted correctly into the EcoRI site of pAc3 plasmid (pAc3-GLUT2) or pCDL-SR $\alpha$ plasmid $(\mathrm{SR} \alpha$-glucokinase $[\mathrm{GK}])$, respectively.

Transfection. AtT20 cells (passage 4 from initiate of cell culture) were plated at a density of $10^{6}$ cells $/ 100 \mathrm{~mm}$ culture dish. After incubation for 3 days, we transfected pAc3-HI into the 
cells using Lipofectin reagent [30]. A clone that stably overexpressed human insulin gene termed AtT20HI cells, was established by isolating colonies resistant to $500 \mu \mathrm{g} / \mathrm{ml}$ of geneticin (G418). Human insulin gene was also transfected into MIN6 cells (MIN6HI cells). By the same lipofection method, pCMV-his and pAc3-GLUT2, or pCMV-his and SR $\alpha-G K$, or pCMV-his, pAc3-GLUT2 and SR $\alpha$-GK, were co-transfected into AtT20HI cells, respectively. Several clones were established by isolating colonies resistant to $5 \mathrm{mmol} / \mathrm{l}$ of L-Histidinol-2 HCl. Of these, a clone (termed AtT20HI-GLUT2-3), that expressed GLUT2, another clone (termed AtT20HI-GK1) that expressed glucokinase, and clones (termed AtT20HIGLUT2-GK-6, AtT20HI-GLUT2-GK-7 and AtT20HIGLUT2-GK-10, respectively) that expressed both GLUT2 and glucokinase were selected for further studies.

Northern blot analysis. Total RNA was prepared using the guanidine isothiocyanate method from the above cells. RNA $(10 \mu \mathrm{g})$ was denatured with formaldehyde, then separated by $1 \%$ agarose gel electrophoresis and transferred onto a nitrocellulose membrane. Northern blot analysis [31] was carried out with a probe of ${ }^{32} \mathrm{P}$-labelled human insulin gene, rat GLUT2 cDNA or rat islet glucokinase cDNA fragment, which was digested by EcoRI from pAc3-HI, pAc3-GLUT2 or SR $\alpha$ GK plasmid, respectively. The radioactive signals obtained were quantified using a BAS 100 bioimaging analyser (Fujix, Fuji Photo Film, Tokyo, Japan).

Western blot analysis. Western blot analysis was done by standard methods using total cellular lysates of the cells [4]. For this purpose, cells were extracted in $5 \%$ sodium dodecyl sulphate (SDS), $80 \mathrm{mmol} / \mathrm{l}$ Tris- $\mathrm{HCl}, \mathrm{pH} 7.8,5 \mathrm{mmol} / \mathrm{l}$ EDTA, $10 \%$ glycerol and $1 \mathrm{mmol} / \mathrm{l}$ phenylmethylsulphonyl fluoride by sonication. In the next step, $50 \mu \mathrm{g}$ of protein was electrophoresed on a $10 \%$ SDS-polyacrylamide gel and transferred onto a nitrocellulose membrane. A rabbit antiserum to rat GLUT2, diluted at 1:500 or a goat antiserum to glucokinase, diluted at 1:1000, was used to detect GLUT2 or glucokinase, respectively. The radioactive signals obtained were quantified using a BAS 100 bioimaging analyser.

Measurement of glucose transport. Measurement of 3-O-methylglucose uptake was done in Hanks' balanced salt solution (HBSS; $120 \mathrm{mmol} / \mathrm{l} \mathrm{NaCl}, 0.14 \mathrm{mmol} / 1 \mathrm{Na}_{2} \mathrm{HPO}_{4}, 2.5 \mathrm{mmol} / \mathrm{l}$ $\mathrm{KH}_{2} \mathrm{PO}_{4}, 0.25 \mathrm{mmol} / 1 \mathrm{MgSO}_{4}, 1.3 \mathrm{mmol} / \mathrm{l} \mathrm{CaCl}$ and $10 \mathrm{mmol} / \mathrm{l}$ HEPES) containing $0.1 \%$ BSA supplemented with 3-O-methyl-D- $\left[{ }^{3} \mathrm{H}\right]$ glucose $(4 \mu \mathrm{Ci} / \mathrm{ml})$ for a period of $20 \mathrm{~s}$ and stopped by the addition of an excess of icecold medium containing $100 \mathrm{mmol} / \mathrm{l}$ glucose [16]. Cells were washed seven times and lysed by the addition of $0.5 \%$ SDS. The radioactivity in the lysate was counted, and the results were corrected for the total cellular protein contents. The $\mathrm{Km}$ and $\mathrm{V}_{\max }$ values were calculated by double-reciprocal Michaelis-Menten plots from four independent experiments.

Glucose phosphorylation. Glucokinase and hexokinase activities in cytoplasmic fractions were measured by the fluorometric methods as described [32]. For this, each cell line was sonicated in $250 \mu \mathrm{l}$ of a buffer ( $\mathrm{pH} 7.0)$ consisting of $20 \mathrm{mmol} / \mathrm{l}$ $\mathrm{KH}_{2} \mathrm{PO}_{4}, 100 \mathrm{mmol} / \mathrm{K} \mathrm{KCl}, 1 \mathrm{mmol} / \mathrm{l} \mathrm{MgCl}_{2}, 1 \mathrm{mmol} / 1$ EDTA, $60 \mathrm{~g} / \mathrm{l}$ glycerol, $1 \mathrm{mmol} / \mathrm{l}$ DTT and $1 \mathrm{~g} / \mathrm{l} \mathrm{BSA}$. For the assay of hexokinase and glucokinase activities, the sonicated sample solution of cell extracts $(25 \mu \mathrm{l})$ and reaction mixtures $(135 \mu \mathrm{l})$ containing $50 \mathrm{mmol} / \mathrm{l}$ HEPES-NaOH buffer ( $\mathrm{pH} 7.4$ ), $100 \mathrm{mmol} / \mathrm{l} \mathrm{KCl}, 8 \mathrm{mmol} / \mathrm{l} \mathrm{MgCl}_{2}, 5 \mathrm{mmol} / \mathrm{l} \mathrm{ATP}, 0.5 \mathrm{mmol} / \mathrm{l}$ $\mathrm{NAD}, 1 \mathrm{mmol} / \mathrm{l} \mathrm{DTT}, 1 \mathrm{~g} / \mathrm{l} \mathrm{BSA}, 1 \mathrm{mmol} \cdot \mathrm{l}^{-1} \cdot \mathrm{min}^{-1}$ glucose6-phosphate dehydrogenase and 0.5 or $50 \mathrm{mmol} / 1$ glucose, were incubated at $37^{\circ} \mathrm{C}$ for $1 \mathrm{~h}$ and the reaction was stopped by the addition of $290 \mu \mathrm{l}$ of the stop buffer ( $\mathrm{pH}$ 8.0) containing $300 \mathrm{mmol} / 1 \mathrm{NaH}_{2} \mathrm{PO}_{4}$ and $0.46 \mathrm{mmol} / \mathrm{l} \mathrm{SDS}$. The fluorescence of NADH was then measured at excitation and emission wavelengths of 340 and $450 \mathrm{~nm}$, respectively. Reagent blanks were measured in the absence of ATP and subtracted from the total fluorescence of the corresponding complete reaction mixtures. The activity of hexokinase was measured at a glucose concentration of $0.5 \mathrm{mmol} / \mathrm{l}$ and glucokinase activity was estimated as the difference between activities at 0.5 and $50 \mathrm{mmol} / \mathrm{l} \mathrm{glu-}$ cose, as described previously [32].

Insulin secretion and content. Static incubation was done under $5 \% \mathrm{CO}_{2}-95 \%$ air environment at $37^{\circ} \mathrm{C}$. Insulin secretion into HBSS containing $0.1 \%$ BSA was measured in the presence of various concentrations of glucose $(0.1,0.5,1,5,10$ or $25 \mathrm{mmol} / \mathrm{l})$ at 15, 30, 60 and $180 \mathrm{~min}$ of incubation. After incubation, the medium was collected and centrifuged, and the supernatant was assayed for immunoreactive insulin (IRI) by RIA using the $\mathrm{Ab}$ Bead Insulin Eiken Radioimmunoassay Kit. For the measurement of intracellular insulin content, the cells were collected in $10 \mathrm{ml}$ of $5 \mathrm{~N}$ acetic acid, lysed by three cycles of freeze-thawing, and lyophilized [18]. The dried lysate was reconstituted in $5 \mathrm{ml}$ of insulin assay buffer and aliquots were assayed for IRI by RIA. The IRI was also corrected for the total cellular protein contents. Glucose stimulated insulin secretion was also measured in the presence of $250 \mu \mathrm{mol} / \mathrm{l}$ diazoxide, $10 \mu \mathrm{mol} / \mathrm{l}$ nifedipine or $5 \mathrm{mmol} / \mathrm{l} 2-\mathrm{DG}$ at 15,30 and $60 \mathrm{~min}$ of incubation. Furthermore, insulin secretion was also measured in the presence of $100 \mu \mathrm{mol} / 1$ glibenclamide, $25 \mathrm{mmol} / \mathrm{l} \mathrm{KCl}$ or $100 \mathrm{nmol} / \mathrm{l} \mathrm{CRF}$ with or without $25 \mathrm{mmol} / \mathrm{l}$ glucose at 15, 30 and 60 min of incubation periods.

In perifusion studies, cells cultured on the surface of plastic microcarrier beads (Biosilon) [33] were incubated in DMEM with $25 \mathrm{mmol} / \mathrm{l}$ glucose and $10 \% \mathrm{FBS}$ for $6 \mathrm{~h}$ at $37^{\circ} \mathrm{C}$. The suspension was then stirred continuously at $30 \mathrm{rpm}$ for 3 days. After incubation, approximately $5 \times 10^{7}$ cells attached on the surface of Biosilon were loaded into a Pharmacia C10/10 column. After washing for $15 \mathrm{~min}$ with glucose-free HBSS, the cells were perifused with HBSS containing $5 \mathrm{mmol} / \mathrm{l}$ glucose for $30 \mathrm{~min}$, and then with HBSS containing $25 \mathrm{mmol} / \mathrm{l}$ glucose for $30 \mathrm{~min}$ at a flow rate $250 \mu \mathrm{l} / \mathrm{min}$. The effluents were collected every $2.5 \mathrm{~min}$, and IRI in effluent samples was assayed by RIA. For control, we used MIN6HI cells (approximately $10^{5}$ cells) and isolated rat islets (batches of 5 islets), which were perfused as described above.

Glucose utilization and oxidation. Glucose metabolism was measured over $2 \mathrm{~h}$ at $37^{\circ} \mathrm{C}$. For this, cells were incubated in $0.3 \mathrm{ml}$ of HBSS with $0.1 \%$ BSA containing various concentrations $(0.1,1,5,10$ and $25 \mathrm{mmol} / \mathrm{l})$ of $25 \mu \mathrm{Ci} / \mathrm{ml} \mathrm{D}-\left[5-{ }^{3} \mathrm{H}\right]$ glucose and $\left.25 \mu \mathrm{Ci} / \mathrm{ml} \mathrm{D-[U-}{ }^{14} \mathrm{C}\right]$ glucose [16]. The conversion of D- $\left[5-{ }^{3} \mathrm{H}\right]$ glucose to ${ }^{3} \mathrm{H}_{2} \mathrm{O}$ was measured simultaneously with the production of ${ }^{14} \mathrm{CO}_{2}$ from $\mathrm{D}-\left[\mathrm{U}_{-}{ }^{14} \mathrm{C}\right]$ glucose. Cellular metabolism was stopped by the addition of $100 \mu \mathrm{l}$ of $0.2 \mathrm{~mol} / \mathrm{l}$ $\mathrm{HCl}$. Furthermore, hydroxy hyamine was used to capture the ${ }^{14} \mathrm{CO}_{2}$ produced. Tritiated water and ${ }^{14} \mathrm{CO}_{2}$ were measured by a liquid scintillation counter.

Statistical analysis. Data were expressed as means \pm SD. When analysis of variance (ANOVA) indicated significant differences between groups, pairwise comparisons were assessed for significance by the method of Bonferroni using the StatView-J 4.02 software (Abacus Concepts Inc., Calif., USA). A $p$ value less than 0.05 was regarded as statistically significant. 


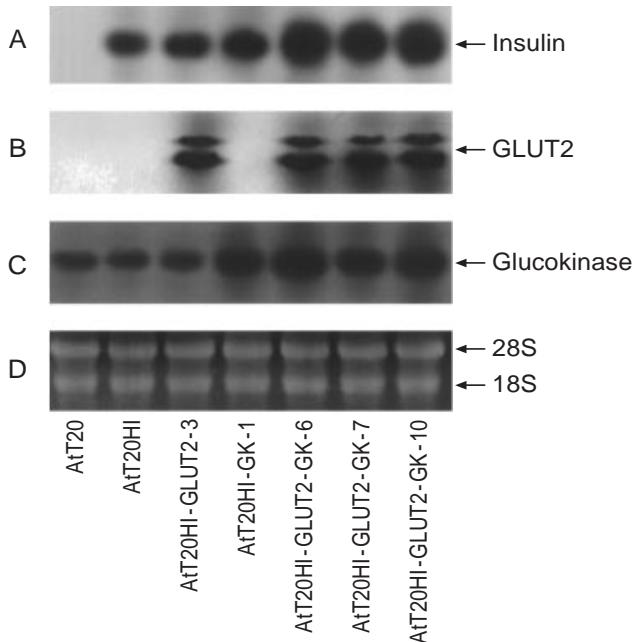

Fig. 1. Northern blot analysis of insulin (A), GLUT2 (B) or glucokinase (C) mRNAs in AtT20 derived cell lines. Total RNA $(10 \mu \mathrm{g})$ from AtT20, AtT20HI, AtT20HI-GLUT2-3, AtT20HI-GK-1, AtT20HI-GLUT2-GK-6, AtT20HI-GLUT2GK-7 or AtT20HI-GLUT2-GK-10 cells was subjected to gel electrophoresis, blotted, and hybridized with the indicated radiolabelled probes as described under "Materials and methods". A and B were exposed for $24 \mathrm{~h}$, and $\mathbf{C}$ was exposed for $72 \mathrm{~h}$. Total cellular RNA electrophoresed on an agarose gel was made visible by ethidium bromide staining $(\mathbf{D})$. The blot shown is representative of four independent experiments

\section{Results}

Northern blot analysis. Transfection of AtT20 cells with pAc3-HI plasmid resulted in several geneticinresistant clones. One, termed AtT20HI cells, which expressed the highest amount of insulin mRNA, was selected and confirmed to secrete human insulin (data not shown). After transfection with rat GLUT2 cDNA or rat islet glucokinase cDNA or both, the mRNA expression of insulin, GLUT2 and islet glucokinase were determined in AtT20HI derived cell lines.

All newly constructed cell lines expressed different levels of human insulin mRNA. AtT20HIGLUT2-3, AtT20HI-GK-1, AtT20HI-GLUT2-GK6, AtT20HI-GLUT2-GK-7 and AtT20HI-GLUT2GK-10 cells expressed approximately 1.5-, 2-, 6-, 4and 5-folds of insulin mRNA, respectively, compared with AtT20HI cells (Fig. 1). Two bands were detected in AtT20HI cell lines transfected with GLUT2 cDNA (AtT20HI-GLUT2-3 and AtT20HI-GLUT2-GK-6, AtT20HI-GLUT2-GK-7 and AtT20HI-GLUT2GK-10 cells). This could be due to differences in the use of poly- $\mathrm{A}^{+}$additional signals in GLUT2 gene and the expression vector. These cell lines expressed almost equal amounts of GLUT2 mRNA, whereas GLUT2 mRNA was not detected in AtT20, AtT20HI or AtT20HI-GK-1 cells (Fig. 1).

AtT20HI and AtT20HI-GLUT2-3 cells expressed small amounts of endogenous glucokinase mRNA,

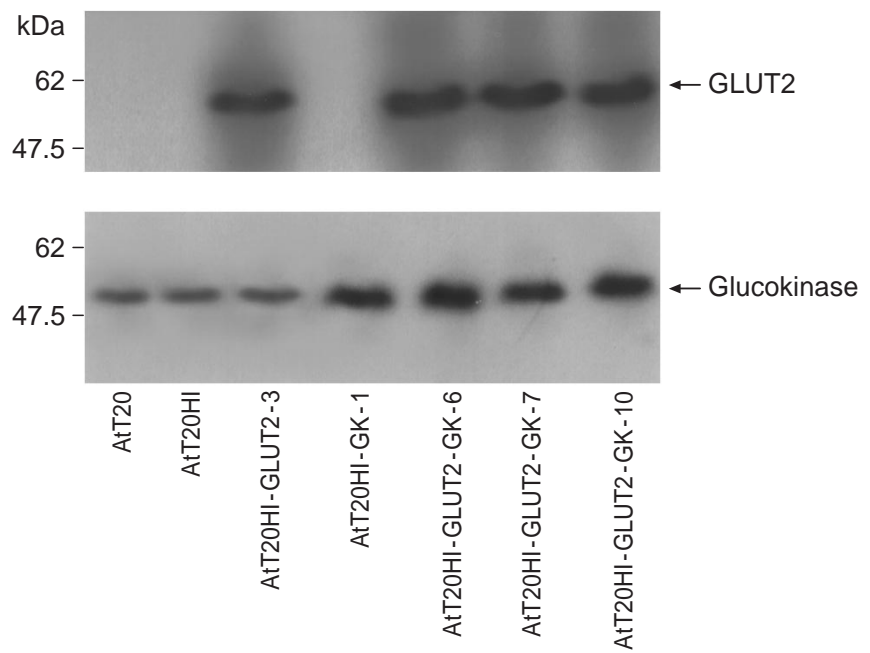

Fig. 2. Expression of GLUT2 or glucokinase protein in AtT20 derived cell lines. Total cellular lysate $(50 \mu \mathrm{g})$ from AtT20, AtT20HI, AtT20HI-GLUT2-3, AtT20HI-GK-1, AtT20HIGLUT2-GK-6, AtT20HI-GLUT2-GK-7 or AtT20HIGLUT2-GK-10 cells was subjected to $10 \%$ SDS-PAGE, transferred onto a nitrocellulose membrane, and hybridized with a rabbit antiserum to rat GLUT2 (A) or a goat antiserum to rat glucokinase (B). The membrane was later incubated with ${ }^{125} \mathrm{I}$ protein A and subjected to autoradiography. The blot shown is representative of three independent experiments

which were comparable with AtT20 cells. In contrast, AtT20HI-GK-1, AtT20HI-GLUT2-GK-6, AtT20HIGLUT2-GK-7 and AtT20HI-GLUT2-GK-10 cells expressed approximately 5-, 8-, 4- and 6-folds of glucokinase mRNA, respectively, compared with AtT20 cells (Fig. 1).

The total cellular RNA made visible by ethidium bromide staining was almost similar in all cell lines (Fig.1). During the whole experimental period, insulin, GLUT2 and glucokinase mRNA levels in the transfected cell lines remained stable, and none of the transfected cell lines exhibited any apparent differences in cell growth and form from parental AtT20 cells.

Western blot analysis. Approximately $55 \mathrm{kDa}$ single bands corresponding to GLUT2 protein were detected in AtT20HI-GLUT2-3, AtT20HI-GLUT2-GK-6, AtT20HI-GLUT2-GK-7 and AtT20HI-GLUT2GK-10 cells (Fig. 2). In contrast, GLUT2 was not detected in AtT20, AtT20HI and AtT20HI-GK-1 cells. AtT20HI cell lines transfected with GLUT2 expressed almost an equal amount of GLUT2 protein. AtT20, AtT20HI and AtT20HI-GLUT2-3 cells expressed small amounts of endogenous glucokinase protein. On the other hand, AtT20HI-GK-1, AtT20HI-GLUT2-GK-6, AtT20HI-GLUT2-GK-7 and AtT20HI-GLUT2-GK-10 cells expressed a comparable amount of glucokinase protein, which was approximately 6-fold to 10-fold higher than in AtT20 cells (Fig. 2). 
Table 1. Kinetic of 3-O-methyl glucose uptake and intracellular insulin content in AtT20 derived cell lines

\begin{tabular}{|c|c|c|c|}
\hline cell type & $\begin{array}{l}\mathrm{Km} \\
(\mathrm{mmol} / \mathrm{l})\end{array}$ & $\begin{array}{l}\mathrm{V}_{\max } \\
\left(\mathrm{mmol} \cdot \min ^{-1} \cdot \mathrm{mg} \text { protein }{ }^{-1}\right)\end{array}$ & $\begin{array}{l}\text { Insulin content } \\
(\mu \mathrm{U} / \mathrm{mg} \text { protein })\end{array}$ \\
\hline AtT20 & $1.5 \pm 0.3$ & $0.8 \pm 0.1$ & not detected \\
\hline AtT20HI & $1.7 \pm 0.4$ & $0.9 \pm 0.3$ & $48.1 \pm 5.9$ \\
\hline AtT20HI-GLUT2-3 & $16.5 \pm 2.1^{\mathrm{a}}$ & $18.2 \pm 3.1^{\mathrm{a}}$ & $56.4 \pm 7.7$ \\
\hline AtT20HI-GK-1 & $2.4 \pm 0.4$ & $1.5 \pm 0.4$ & $61.5 \pm 7.5$ \\
\hline AtT20HI-GLUT2-GK-6 & $18.9 \pm 2.0^{\mathrm{a}}$ & $22.0 \pm 3.3^{\mathrm{a}}$ & $90.7 \pm 13.7^{b}$ \\
\hline AtT20HI-GLUT2-GK-7 & $15.3 \pm 1.8^{\mathrm{a}}$ & $16.9 \pm 2.4^{\mathrm{a}}$ & $80.7 \pm 7.7^{\mathrm{b}}$ \\
\hline AtT20HI-GLUT2-GK-10 & $17.7 \pm 1.5^{\mathrm{a}}$ & $20.5 \pm 2.8^{\mathrm{a}}$ & $83.2 \pm 8.9^{\mathrm{b}}$ \\
\hline
\end{tabular}

The $\mathrm{Km}$ and $\mathrm{V}_{\max }$ values were calculated from four independent experiments. Intracellular insulin contents were measured for five independent experiments. Data are means \pm SD.
${ }^{\mathrm{a}} p<0.05$ compared with AtT20 cells $\left(\mathrm{Km}\right.$ and $\left.\mathrm{V}_{\max }\right) .{ }^{\mathrm{b}} p<0.05$ compared with AtT20HI cells (insulin content)
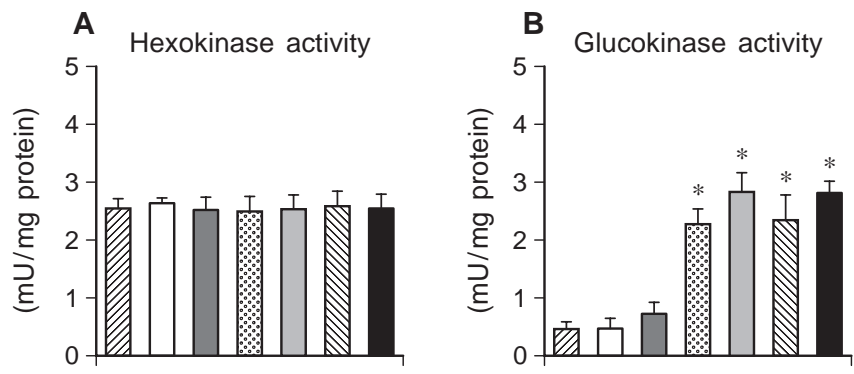

Fig.3A, B. Determination of glucose phosphorylating enzymatic activities in AtT20 derived cell lines. Cells were incubated at $37^{\circ} \mathrm{C}$ for $1 \mathrm{~h}$ in reaction mixtures containing 0.5 or $50 \mathrm{mmol} / \mathrm{l}$ glucose. The fluorescence of NADH was then measured at excitation and emission wavelengths of 340 and 450 $\mathrm{nm}$, respectively. Hexokinase activity (A) was measured at a glucose concentration of $0.5 \mathrm{mmol} / \mathrm{l}$, and glucokinase activity (B) represented the difference between activities at 0.5 and $50 \mathrm{mmol} / 1$ glucose in AtT20 (ש), AtT20HI ( $\square$ ), AtT20HI-

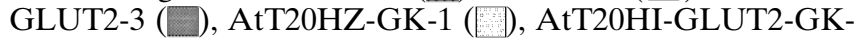

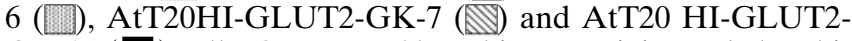

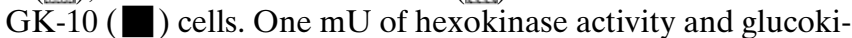
nase activity corresponds to the formation of $1 \mathrm{nmol} \mathrm{NADH}$ over $1 \mathrm{~min}$, respectively. Data are means \pm SD of six independent experiments. ${ }^{*} p<0.05$ compared with AtT20 cells

Measurement of glucose transport. We also measured 3-O-methylglucose uptake into AtT20HI derived cell lines to evaluate the effects of GLUT2 expression. As shown in Table $1, \mathrm{Km}$ and $\mathrm{V}_{\max }$ values in AtT20HI cells were not different from those in AtT20 cells. The effect of overexpression of glucokinase in AtT20 HI cells on glucose transport activity was negligible. In contrast, cell lines that overexpressed GLUT2 (AtT20HI-GLUT2-3, AtT20HI-GLUT2GK-6, AtT20HI-GLUT2-GK-7 and AtT20HIGLUT2-GK-10 cells) exhibited 10.2-fold to 12.6-fold higher $\mathrm{Km}$ for 3-O-methylglucose and 21.1-fold to 27.5-fold higher $\mathrm{V}_{\max }$ than in AtT20 cells.

Glucose phosphorylation. To evaluate the effect of glucokinase expression in AtT20HI derived cell lines, we measured hexokinase and glucokinase activities in cytoplasmic fractions by using the fluorometric methods. Hexokinase activity was similar in all cell lines (Fig. 3). In contrast, glucokinase activity in At-
T20HI-GK-1, AtT20HI-GLUT2-GK-6, AtT20HIGLUT2-GK-7 and AtT20HI-GLUT2-GK-10 cells was higher $(p<0.05)$ by 4.1-, 5.5-, 4.2- and 5.3-folds, respectively, than in AtT20 cells (glucokinase activity in AtT20, AtT20HI-GK-1, AtT20HI-GLUT2-GK-6, AtT20HI-GLUT2-GK-7 and AtT20HI-GLUT2GK-10 cells, $0.45 \pm 0.13,2.28 \pm 0.28, \quad 2.92 \pm 0.31$, $2.34 \pm 0.42$ and $2.85 \pm 0.20 \mathrm{mU} / \mathrm{mg}$ protein, respectively, Fig.3). The ratio of glucose phosphorylating activity (glucokinase vs hexokinase) was 0.9, 1.2, 0.9 and 1.1 in AtT20HI-GK-1, AtT20HI-GLUT2-GK-6, AtT20HI-GLUT2-GK-7 and AtT20HI-GLUT2GK-10 cells, respectively. Augmentation of glucokinase activity paralleled increased levels of glucokinase mRNA and protein shown in Figure 1 and 2.

Insulin secretion. In the next series of experiments we analysed the insulin-like immunoreactivity secreted from AtT20HI cells by HPLC. Approximately $85 \%$ of insulin-like immunoreactivity secreted from AtT20HI cells corresponded to the same fraction of human insulin that was eluted as a standard (data not shown).

In static incubation studies, we examined insulin secretion in AtT20HI derived cell lines in response to different concentrations of glucose. Insulin secretion at 60 min was of the same order at all glucose concentrations evaluated (Fig. 4); with the highest secretion in AtT20HI-GLUT2-GK cell lines, followed by that in AtT20HI-GK-1, AtT20HI-GLUT2-3 and AtT20HI cells. AtT20HI cells showed no response to glucose. Insulin secretion in AtT20HI-GLUT2-3 and AtT20HI-GK-1 cells was glucose-dependent at concentrations less than $1 \mathrm{mmol} / \mathrm{l}$ glucose. In contrast, insulin secretion in AtT20HI-GLUT2-GK-6, AtT20HI-GLUT2-GK-7 and AtT20HI-GLUT2GK-10 cells was glucose-dependent up to a concentration of $25 \mathrm{mmol} / \mathrm{l}$ glucose. After incubation with $0.1 \mathrm{mmol} / 1$ glucose for $60 \mathrm{~min}$, intracellular insulin contents of AtT20HI-GLUT2-GK-6, AtT20HIGLUT2-GK-7 and AtT20HI-GLUT2-GK-10 cells increased by 1.9-, 1.7- and 1.7-folds, respectively, compared with AtT20HI cells (Table 1). Insulin contents at $0.1 \mathrm{mmol} / 1$ glucose in AtT20HI-GLUT2-3 


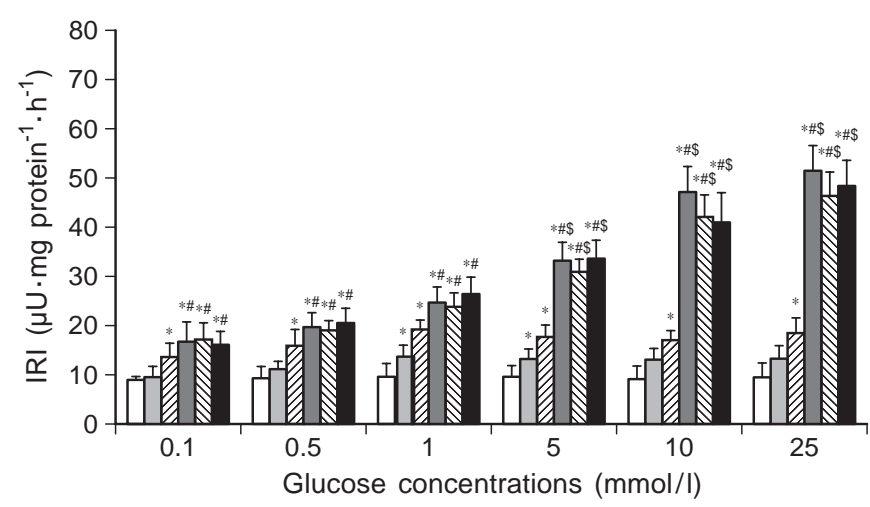

Fig. 4. Effect of glucose concentration on insulin secretion in AtT20 cell lines overexpressing insulin gene and GLUT2 or glucokinase genes or both. Insulin secreted from AtT20HI (口), AtT20HI-GLUT2-3 ([1), AtT20HI-GK-1 (U), At-

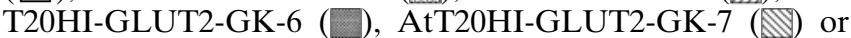
AtT20HI-GLUT2-GK-10 ( $\square$ ) cells was measured after 60min incubation with various concentrations of glucose $(0.1$, $0.5,1,5,10$ or $25 \mathrm{mmol} / \mathrm{l})$. Data are corrected for the total cellular protein contents and represent the means \pm SD of five independent experiments. *, \#, $\$: p<0.05$ compared with AtT20HI, AtT20HI-GLUT2-3 and AtT20HI-GK-1 cells at each glucose concentration, respectively
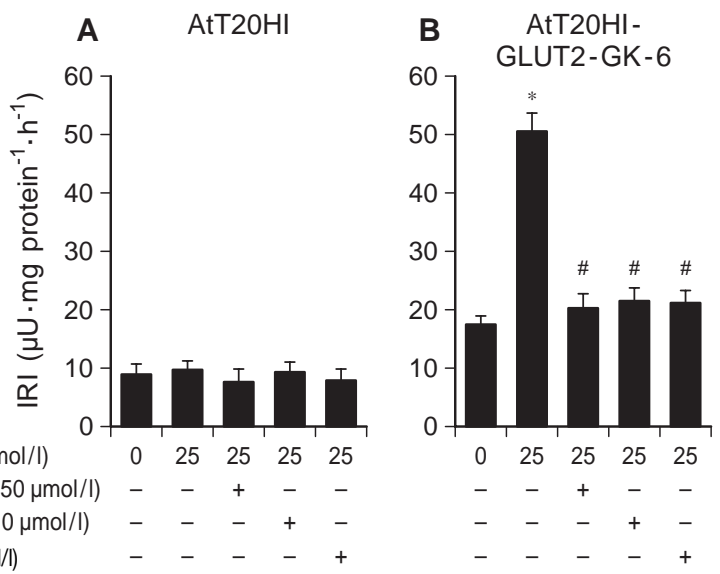

Fig. 5A, B. Effect of diazoxide, nifedipine and 2-DG on glucose stimulated insulin secretion in AtT20HI or AtT20HIGLUT2-GK-6 cells. Cells were incubated for $60 \mathrm{~min}$ in HBSS containing $25 \mathrm{mmol} / \mathrm{l}$ glucose in the presence or absence of $250 \mu \mathrm{mol} / \mathrm{l}$ diazoxide, $10 \mu \mathrm{mol} / \mathrm{l}$ nifedipine or $5 \mathrm{mmol} / \mathrm{l} 2-\mathrm{DG}$. Insulin secretion in AtT20HI (A) or AtT20HI-GLUT2-GK-6 cells (B) was measured by RIA. Data are corrected for total cellular protein contents and represent the means \pm SD of six independent experiments. *: $p<0.05$ compared with control (no glucose), \#: $p<0.05$ compared with $25 \mathrm{mmol} / \mathrm{l}$ glucose alone

and AtT20HI-GK-1 cells were also higher than in AtT20HI cells, albeit insignificantly.

We also measured glucose stimulated insulin secretion in the presence of $250 \mu \mathrm{mol} / 1$ diazoxide, $10 \mu \mathrm{mol} / \mathrm{l}$ nifedipine or $5 \mathrm{mmol} / \mathrm{l} 2$-DG. After incubation for $60 \mathrm{~min}$, glucose had no effect on insulin secretion in AtT20HI cells. Diazoxide, nifedipine as well
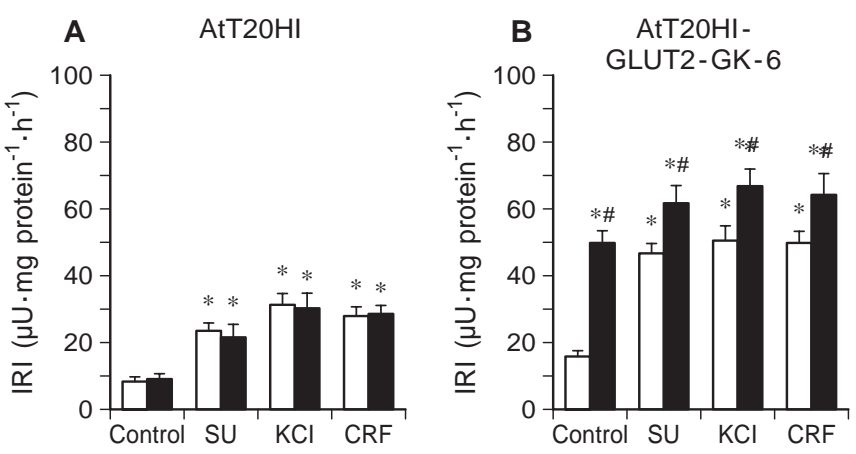

Fig. 6A, B. Effects of glibenclamide, $\mathrm{KCl}$ and $\mathrm{CRF}$ on insulin secretion in AtT20HI or AtT20HI-GLUT2-GK-6 cells. Cells were incubated for $60 \mathrm{~min}$ in HBSS containing $100 \mu \mathrm{mol} / \mathrm{l}$ glibenclamide (SU), $25 \mathrm{mmol} / \mathrm{l} \mathrm{KCl}$ or $100 \mathrm{nmol} / \mathrm{l} \mathrm{CRF}$ in the presence ( $\square$ ) or absence $(\square)$ of $25 \mathrm{mmol} / 1$ glucose. Insulin secretion in AtT20HI (A) or AtT20HI-GLUT2-GK-6 cells (B) was measured by RIA. Data are corrected for total cellular protein contents and represent the means \pm SD of six independent experiments. Control: AtT20HI (A) or AtT20HI-GLUT2-GK-6 cells (B) without any secretagogues. *: $p<0.05$ compared with control without glucose, \#: $p<0.05$ compared with the value of the same secretagogues without glucose

as 2-DG did not influence insulin secretion (Fig.5). The response of AtT20HI-GLUT2-3 and AtT20HIGK-1 cells to diazoxide, nifedipine and 2-DG was similar to that of AtT20HI cells (data not shown). In AtT20HI-GLUT2-GK-6 cells, insulin secretion was higher in the presence of $25 \mathrm{mmol} / \mathrm{l}$ glucose $(p<0.05)$ than in the absence of glucose. Such glucose stimulated insulin secretion was, however, suppressed $(p<0.05)$ by diazoxide, nifedipine and 2-DG (Fig. 5).

The effect of a number of secretagogues, including $100 \mu \mathrm{mol} / \mathrm{l}$ glibenclamide, $25 \mathrm{mmol} / \mathrm{l} \mathrm{KCl}$ and 100 $\mathrm{nmol} / \mathrm{l} \mathrm{CRF}$, on insulin secretion in AtT20HI and AtT20HI-GLUT2-GK-6 cells was measured after $60 \mathrm{~min}$ incubation with or without $25 \mathrm{mmol} / 1$ glucose. In the absence of glucose, glibenclamide, $\mathrm{KCl}$ or CRF stimulated $(p<0.05)$ insulin secretion in both cells, compared with that of control (Fig. 6). Insulin secretion by glibenclamide, $\mathrm{KCl}$ or $\mathrm{CRF}$ was further enhanced in the presence of $25 \mathrm{mmol} / 1$ glucose in AtT20HI-GLUT2-GK-6 cells but not in AtT20HI cells $(p<0.05)$. A response similar to that of AtT20HIGLUT2-GK-6 cells was observed in AtT20HIGLUT2-GK-7 and AtT20HI-GLUT2-GK-10 cells (data not shown).

To study the dynamics of insulin secretion and to compare the concentrations of glucose stimulated insulin secretion between isolated rat islets and AtT20HI-GLUT2-GK-6 cells, we conducted a series of perifusion experiments using AtT20HI, AtT20HIGLUT2-GK-6, MIN6HI cells as well as isolated rat islets. Perifusion with glucose-free HBSS for $15 \mathrm{~min}$ resulted in a gradual fall in insulin secretion in each cell line, but reached a steady state after the first 


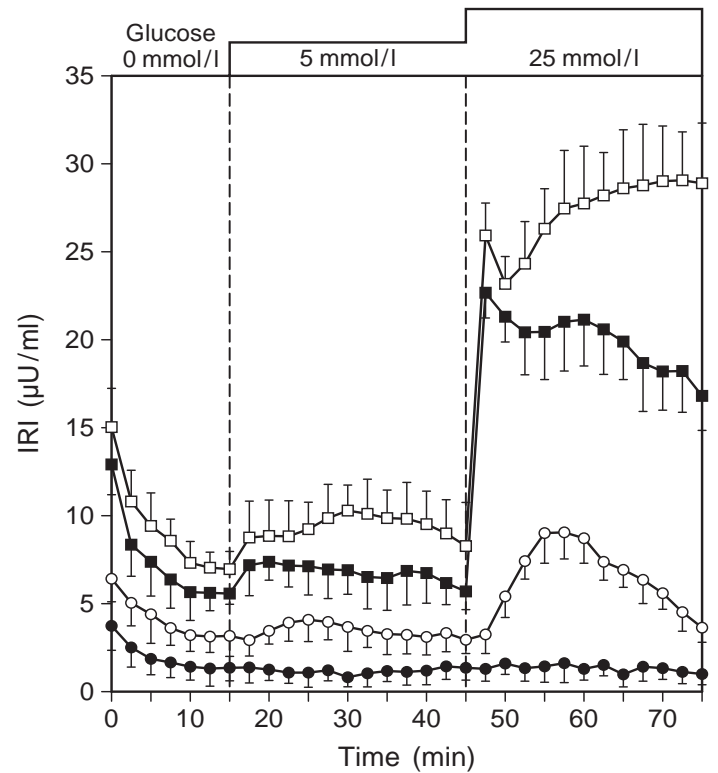

Fig.7. Glucose stimulated insulin secretion in perifused AtT20HI, AtT20HI-GLUT2-GK-6, MIN6HI cells and isolated rat islets. AtT20HI $\left(5 \times 10^{7}\right.$ cells $)(0)$, AtT20HI-GLUT2GK-6 $\left(5 \times 10^{7}\right.$ cells) $(\bigcirc)$ or MIN6HI $\left(10^{5}\right.$ cells $)(\boldsymbol{\square})$ cells attached to the surface of Biosilon or isolated rat islets (batches of 5 islets) ( $\square$ ) were loaded into a column and perifused with HBSS containing $5 \mathrm{mmol} / \mathrm{l}$ glucose for $30 \mathrm{~min}$ followed by HBSS containing $25 \mathrm{mmol} / \mathrm{l}$ glucose for $30 \mathrm{~min}$ at a flow rate of $250 \mu \mathrm{l} / \mathrm{min}$. Fractions of the perifusate were collected every $2.5 \mathrm{~min}$ and analysed for IRI by RIA. Data are the means \pm $\mathrm{SD}$ of five independent experiments
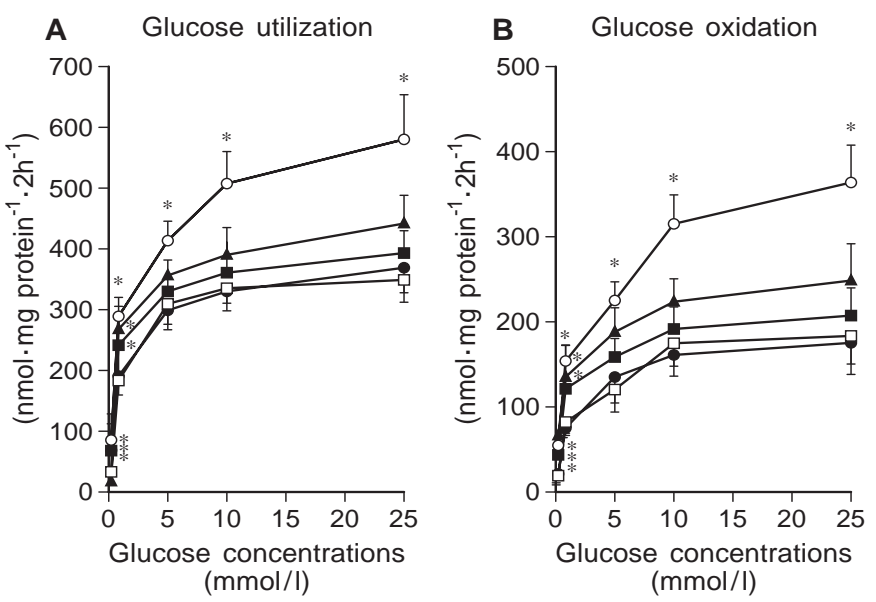

Fig. 8A, B. Glucose utilization and oxidation in AtT20 derived cell lines. Glucose utilization (A) was measured as ${ }^{3} \mathrm{H}_{2} \mathrm{O}$ production from D- $\left[5-{ }^{3} \mathrm{H}\right]$ glucose and oxidation $(\mathbf{B})$ as ${ }^{14} \mathrm{CO}_{2}$ output from D-[U- $\left.{ }^{14} \mathrm{C}\right]$ glucose in AtT20 (O), AtT20HI ( $\left.\square\right)$, At-

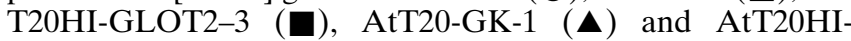
GLUT2-GK-6 (O) cells. Data are corrected for total cellular protein contents and represent the means \pm SD of four independent experiments. *: $p<0.05$ compared with AtT20 cells
10 min (Fig. 7). Perifusion with HBSS containing $5 \mathrm{mmol} / \mathrm{l}$ glucose had no effects on insulin secretion in AtT20HI cells but slightly increased the secretion in AtT20HI-GLUT2-GK-6, MIN6HI cells and isolated rat islets. A biphasic pattern of insulin secretion in response to glucose was observed, however, in isolated rat islets and MIN6HI cells when glucose concentration in the perifusate was increased from 5 to $25 \mathrm{mmol} / \mathrm{l}$, although the second phase of the response of MIN6HI cells gradually diminished with time. Although AtT20HI-GLUT2-GK-6 cells showed a secretory response following stimulation with $25 \mathrm{mmol} / 1$ glucose, the response lacked a clear initial peak which was observed in isolated rat islets and MIN6HI cells. The response of AtT20HI-GLUT2GK-7 and AtT20HI-GLUT2-GK-10 cells was similar to that of AtT20HI-GLUT2-GK-6 cels (data not shown).

Glucose utilization and oxidation. Finally, we measured the glucose concentration-dependence of utilization and oxidation by measuring the production of ${ }^{3} \mathrm{H}_{2} \mathrm{O}$ from $\left[5^{3} \mathrm{H}\right]$ glucose and ${ }^{14} \mathrm{CO}_{2}$ from $\left[{ }^{14} \mathrm{C}\right]$ glucose, respectively, in AtT20 derived cell lines. Glucose utilization and oxidation in AtT20HI-GLUT2GK-6 cells were increased $(p<0.05)$ at all glucose concentrations tested, compared with AtT20 and AtT20HI cells. In AtT20HI-GLUT2-3 and AtT20HIGK-1 cells, glucose utilization and oxidation were high at low glucose concentrations compared with AtT20 and AtT20HI cells, but not at $5 \mathrm{mmol} / \mathrm{l}$ or higher glucose (Fig. 8).

\section{Discussion}

AtT20 cells transfected with human insulin gene represent a useful model system of beta cells based on a number of biochemical similarities. In this study, mature human insulin was secreted from AtT20HI derived cell lines as detected by HPLC (data not shown). Furthermore, these cell lines secreted insulin in response to CRF. These results are in agreement with previous reports suggesting that adrenocorticotropic hormone $(\mathrm{ACTH})$ and insulin are stored in the same secretory granules, transported to the regulatory pathway and secreted together in response to secretagogues in AtT20 cells transfected with insulin gene $[18-22,32,34]$.

Our initial results showed that AtT20HI cells secreted mature human insulin but failed to show glucose stimulated insulin secretion. We postulated that this could be due to differences in the expression of GLUT2 or glucokinase or both between beta and AtT20HI cells. Therefore, we constructed AtT20HI cells with overexpressed GLUT2 or glucokinase or both and studied their cellular characteristics. We found that AtT20HI-GLUT2-3 and AtT20HI-GK-1 
cells secreted insulin after stimulation with glucose at concentrations lower than that required for insulin secretion in beta cells. These cell lines expressed higher insulin mRNAs, but only a slight increase in insulin contants, than in AtT20HI cells. Our results also showed that glucose utilization and oxidation in these cell lines were both high at subphysiological glucose concentrations, but not at physiological glucose concentrations. More importantly, AtT20HIGLUT2-GK cell lines exhibited a glucose-dependent insulin secretion up to a concentration of $25 \mathrm{mmol} / \mathrm{l}$. The level of insulin mRNA and glucose metabolism in these cell lines were also high compared with AtT20HI cells. The reason for the overexpressed insulin mRNA in these cells is not clear but it could be due to a high rate of glucose metabolism in AtT20HIGLUT2-GK cell lines. This argument is supported by the finding that the stability of insulin mRNA is upregulated by increased glucose-induced signal [35]. Another important finding of our study was that not overexpression of GLUT2 or glucokinase alone but rather a sufficient expression of both was necessary to stimulate insulin secretion in AtT20HI cell lines in response to stepwise increases in glucose concentration.

Our results also showed a high activity of glucokinase (almost similar or even more than that of hexokinase) in AtT20HI-GLUT2-GK cell lines. Previous studies have shown that this activity is similar or higher than that of hexokinase in beta cells [6, 22]. The importance of glucokinase expression in beta cells is also supported by studies in mice with targeted disruption of the pancreatic glucokinase gene. These studies found that not necessarily qualitative abnormality but simple reduction in quantity of glucokinase was sufficient to cause diabetes in mice $[14,15]$. More recently, the importance of glucokinase expression was also reported in experiments using engineered beta cell lines [36]. In these studies, $\beta \mathrm{G} 49 /$ 206 cells (transfected with insulin, GLUT2 and glucokinase gene) and $\beta \mathrm{G} \mathrm{40/110} \mathrm{cells} \mathrm{(transfected} \mathrm{with}$ insulin and glucokinase gene) exhibited potent insulin secretory responses to glucose that were clearly higher than the corresponding response of $\beta \mathrm{G} \mathrm{I} / 17$ cells (transfected with insulin gene alone) or parental RIN1046-38 cells. Although, $\beta \mathrm{G} \mathrm{49/206}$ and $\beta \mathrm{G} \mathrm{40/}$ 110 cells exhibited a decrease in basal insulin secretion and insulin content compared with $\beta \mathrm{G} \mathrm{I} / 17$ cells [36]. In our study using non-beta cell lines (AtT20HI-GLUT2-GK cell lines), basal insulin secretion and insulin content were higher than that in AtT20HI cells. The reason for the difference between AtT20HI-GLUT2-GK and RIN1046-38-cell lines is still to be explained. It is possible that beta cell lines contain some other elements or activate other mechanisms to regulate insulin secretion, which are otherwise absent in AtT20 derived cell lines [8, 37]. Moreover, our study showed that glucose stimulated insu- lin secretion in AtT20HI-GLUT2-GK-6 cell was suppressed by the addition of 2-DG. The latter is known to inhibit mainly the activity of hexokinase but not that of glucokinase [22]. The mechanism of the inhibitory effect of 2-DG on glucose stimulated insulin secretion is not clear, although similar results have been reported previously $[38,39]$, and has to be clarified by future studies using knock-out models.

The present study also showed that insulin secretion in AtT20HI-GLUT2-GK-6 cells in response to glucose was suppressed following the addition of diazoxide or nifedipine. In the absence of glucose, glibenclamide or $\mathrm{KCl}$ stimulated insulin secretion in both AtT20HI and AtT20HI-GLUT2-GK-6 cells. Diazoxide is reported to block insulin secretion by preventing agonist-induced increases in ATP through the closure of ATP-sensitive $\mathrm{K}^{+}$channels $[9,10,40]$. On the other hand, nifedipine inhibits $\mathrm{Ca}^{2+}$ influx and antagonizes the ability of glucose to increase cytosolic $\mathrm{Ca}^{2+}$, and therefore, blocks insulin secretion $[7,9,10,41]$. Sulphonylurea inhibits the activity of ATP-sensitive $\mathrm{K}^{+}$channel by binding to its specific receptors, which are considered to be a subunit of the ATP-sensitive $\mathrm{K}^{+}$channel [42]. Other studies have found that the sulphonylurea receptor 1 (SUR1) [43, 44] and dihydropyridine-sensitive $\mathrm{Ca}^{2+}$ channel [45] are also expressed in AtT20 cells as in beta cells. The results of these early studies and our findings combined suggest that glucose stimulated insulin secretion is mainly regulated through ATP-sensitive $\mathrm{K}^{+}$channels and voltage-dependent $\mathrm{Ca}^{2+}$ channels in AtT20HI-GLUT2-GK cell lines as well as in beta cells.

Our results also showed that sulphonylurea or $\mathrm{KCl}$ further enhanced insulin secretion in response to high concentrations of glucose. This response, noted in AtT20HI-GLUT2-GK-6 cells but not in AtT20HI cells, suggests that the enhanced secretion of insulin by glucose, sulphonylurea or $\mathrm{KCl}$ occurred through a common pathway. Furthermore, high concentrations of glucose possibly trigger another signal that further enhances insulin secretion and control the membrane potential after closure of the ATP-sensitive $\mathrm{K}^{+}$channel. Alternatively, the enhanced secretion of insulin in response to high concentrations of glucose could occur, at least in part, through other pathways that are independent of ATP-sensitive $\mathrm{K}^{+}$channel $[9,10]$.

It is noteworthy that insulin secretion in response to various secretagogues (e.g. glucose, sulphonylurea and $\mathrm{KCl}$ ), and inhibitors (e.g. diazoxide and nifedipine) in non-beta cell lines transfected with insulin, GLUT2 and glucokinase, was similar to that in normal beta cells.

Perifusion experiments in this study indicated that AtT20HI-GLUT2-GK-6 cells increased insulin secretion in response to $25 \mathrm{mmol} / \mathrm{l}$ glucose, however the response lacked a clear first phase of insulin secretion observed in isolated rat islets (Fig. 7). It has been sug- 
gested that the first phase of insulin secretion is due to a transient increase in $\mathrm{Ca}^{2+}$ released from the intracellular storage pool into the cytosole [46]. It was hypothesized that mobilization of $\mathrm{Ca}^{2+}$ from the intracellular storage pool acts to stimulate the phosphorylation of a subset of cellular proteins that mediate the first phase of insulin secretion and that the activation of protein kinase $\mathrm{C}$ plays a particularly important part in the second phase of insulin secretion [46, 47]. Therefore, the lack of a rapid insulin response to high concentrations of glucose in AtT20HI-GLUT2GK cell lines is perhaps due to the absence of the signals of $\mathrm{Ca}^{2+}$ messenger system that leads to a transient increase in intracellular $\left[\mathrm{Ca}^{2+}\right]$.

In conclusion, we successfully constructed nonbeta cell lines that secreted insulin in response to physiological concentrations of glucose by expression of insulin, GLUT2 and glucokinase genes in AtT20 cells. Furthermore, the patterns of insulin secretion in response to various agents in these cell lines were also similar to those in normal beta cells. Our cell lines failed to show a clear first phase of insulin secretion in response to glucose, however, suggesting that element(s) other than GLUT2 and glucokinase might be also necessary for the development of the typical biphasic insulin secretion observed in normal beta cells.

Acknowledgements. We thank Dr. J. Miyazaki, Osaka University School of Medicine, for providing MIN6 cells and pAc3 plasmid. The technical assistance of $\mathrm{K}$. Ichinose is gratefully acknowledged.

This work was supported in part by a grant for chronic disease research from the Ministry of Health and Welfare of Japan, a grant from the Study Group for Pathogenesis and Prevention of NIDDM, Japan, and a grant for scientific research from the Ministry of Education, Science and Culture of Japan (No. 06557061).

\section{References}

1. DeFronzo RA (1992) Pathogenesis of Type2 (non-insulin dependent) diabetes mellitus: a balanced overview. Diabetologia 35: 389-397

2. Taylor R, Agius L (1988) The biochemistry of diabetes. Biochem J 250: 625-640

3. McGarry JD (1992) What if Minkowski had been ageusic? An alternative angle on diabetes. Science 258: 766-770

4. Thorens B, Sarkar HK, Kaback HR, Lodish HF (1988) Cloning and functional expression in bacteria of a novel glucose transporter present in liver, intestine, kidney, and $\beta$-pancreatic islet cells. Cell 55: 281-290

5. Newgard CB, Quaade C, Hughes SD, Milburn JL (1990) Glucokinase and glucose transporter expression in liver and islets: implications for control of glucose homeostasis. Biochem Soc Trans 18: 851-853

6. Matschinsky FM, Sweet IR (1996) Annotated questions and answers about glucose metabolism and insulin secretion of $\beta$-cells. Diabetes Rev 4: 130-144

7. Rorsman P (1997) The pancreatic beta-cell as a fuel sensor: an electrophysiologist's viewpoint. Diabetologia 40: 487-495
8. Matschinsky FM (1996) Banting lecture 1995: a lesson in metabolic regulation inspired by the glucokinase glucose sensor paradigm. Diabetes 45: 223-241

9. Gembal M, Detimary P, Gilon P, Gao ZY, Henquin JC (1993) Mechanisms by which glucose can control insulin release independently from its action on adenosine triphosphate-sensitive $\mathrm{K}^{+}$channels in mouse B cells. J Clin Invest 91: 871-880

10. Komatsu M, Schermerhorn T, Aizawa T, Sharp GWG (1995) Glucose stimulation of insulin release in the absence of extracellular $\mathrm{Ca}^{2+}$ and in the absence of any increase in intracellular $\mathrm{Ca}^{2+}$ in rat pancreatic islets. Proc Natl Acad Sci USA 92: 10728-10732

11. Johnson JH, Ogawa A, Chen L et al. (1990) Underexpression of $\beta$ cell high $\mathrm{Km}$ glucose transporters in noninsulindependent diabetes. Science 250: 546-549

12. Unger RH (1991) Diabetic hyperglycemia: link to impaired glucose transport in pancreatic $\beta$ cells. Science 251: 1200-1205

13. Vionnet N, Stoffel M, Takeda J et al. (1992) Nonsense mutation in the glucokinase gene causes early-onset non-insulin-dependent diabetes mellitus. Nature 356: 721-722

14. Grupe A, Hultgren B, Ryan A, Ma YH, Bauer M, Stewart TA (1995) Transgenic knockouts reveal a critical requirement for pancreatic $\beta$ cell glucokinase in maintaining glucose homeostasis. Cell 83: 69-78

15. Terauchi Y, Sakura H, Yasuda K et al. (1995) Pancreatic $\beta$ cell-specific targeted disruption of glucokinase gene. J Biol Chem 270: 30253-30256

16. De Vos A, Heimberg H, Quartier et al. (1995) Human and rat beta cells differ in glucose transporter but not in glucokinase gene expression. J Clin Invest 96: 2489-2495

17. Ferrer J, Benito C, Gomis R (1995) Pancreatic islet GLUT2 glucose transporter mRNA and protein expression in humans with and without NIDDM. Diabetes 44: $1369-1374$

18. Moore HPH, Walker MD, Lee F, Kelly RB (1983) Expressing a human proinsulin cDNA in a mouse ACTH-secreting cell. Intracellular storage, proteolytic processing, and secretion on stimulation. Cell 35: 531-538

19. Orci L, Ravazzola M, Amherdt M, Madsen O, Vassalli JD, Perrelet A (1985) Direct identification of prohormone conversion site in insulin-secreting cells. Cell 42: 671-681

20. Hughes SD, Johnson JH, Quaade C, Newgard CB (1992) Engineering of glucose-stimulated insulin secretion and biosynthesis in non-islet cells. Proc Natl Acad Sci USA 89: 688-692

21. Hughes SD, Quaade C, Johnson JH, Ferber S, Newgard CB (1993) Transfection of AtT-20ins cells with GLUT-2 but not GLUT-1 confers glucose-stimulated insulin secretion. J Biol Chem 268: 15205-15212

22. Newgard CB, Hughes SD, Quaade C, Beltrandelrio H, Gomez-Foix AM, Ferber S (1993) Molecular engineering of the pancreatic $\beta$-cell. J Lab Clin Med 122: 356-363

23. Irminger JC, Vollenweider FM, Neerman-Arbez M, Halban PA (1994) Human proinsulin conversion in the regulated and the constitutive pathways of transfected AtT20 cells. J Biol Chem 269: 1756-1762

24. Liang Y, Jetton TL, Zimmerman EC, Najafi H, Matschinsky FM, Magnuson MA (1991) Effects of alternate RNA splicing on glucokinase isoform activities in the pancreatic islet, liver and pituitary. J Biol Chem 266: 6999-7007

25. Hughes SD, Quaade C, Milburn JL, Cassidy L, Newgard CB (1991) Expression of normal and novel glucokinase mRNAs in anterior pituitary and islet cells. J Biol Chem 266: $4521-4530$ 
26. Miyazaki J, Araki K, Yamato E et al. (1990) Establishment of a pancreatic $\beta$ cell line that retains glucose-inducible insulin secretion: special reference to expression of glucose transporter isoforms. Endocrinology 127: 126-132

27. Bell GI, Pictet RL, Rutter WJ, Cordell B, Tischer E, Goodman HM (1980) Sequence of the human insulin gene. Nature 284: 26-31

28. Miyazaki J, Takaki S, Araki K et al. (1989) Expression vector system based on the chicken $\beta$-actin promoter directs efficient production of interleukin-5. Gene 79: 269-277

29. Andreone TL, Printz RL, Pilkis SJ, Magnuson MA, Granner DK (1989) The amino acid sequence of rat liver glucokinase deduced from cloned cDNA. J Biol Chem 264: 363-369

30. Felgner PL, Gadek TR, Holm M et al. (1987) Lipofection: a highly efficient, lipid-mediated DNA-transfection procedure. Proc Natl Acad Sci USA 84: 7413-7417

31. Maniatis T, Fritsch EF, Sambrook J (1982) Molecular cloning. A laboratory manual Cold Spring Harbor Laboratory. Cold Spring Harbor, New York, pp 196-203

32. Miwa I, Mita Y, Murata T et al. (1995) Utility of 3-O-methyl-N-acetyl-D-glucosamine, an $\mathrm{N}$-acetylglucosamine kinase inhibitor, for accurate assay of glucokinase in pancreatic islets and liver. Enzyme Protein 48: 135-142

33. Johansson A, Nielsen V (1980) Biosilon a new microcarrier. Dev Biol Stand 46: 125-129

34. Smeekens SP, Montag AG, Thomas G et al. (1992) Proinsulin processing by the subtilisin-related proprotein convertases furin, PC2, and PC3. Proc Natl Acad Sci USA 89: $8822-8826$

35. Welsh M, Nielsen DA, MacKrell AJ, Steiner DF (1985) Control of insulin gene expression in pancreatic $\beta$-cells and in an insulin-producing cell line, RIN-5F cells. J Biol Chem 260: 13590-13594

36. Hohmeier HE, BeltrandelRio H, Clark SA, Henkel-Rieger R, Normington K, Newgard CB (1997) Regulation of insulin secretion from novel engineered insulinoma cell lines. Diabetes 46: 968-977
37. Van Schaftingen E, Detheux M, Da Cunha MV (1994) Short-term control of glucokinase activity: role of a regulatory protein. FASEB J 8: 414-419

38. Noda M, Komatsu M, Sharp GWG (1996) The $\beta$ HC-9 pancreatic $\beta$-cell line preserves the characteristics of progenitor mouse islets. Diabetes 45: 1766-1773

39. Kimura I, Nakashima N, Kompri T, Kameda Y, Kimura M (1994) Dependence of cholecystokinin-8-stimulated insulin release on high glucose levels is evidenced by pseudo-alpha-D-glucose in rat pancreas and islets. Jpn J Pharmacol 64: 103-107

40. Henquin JC, Charles S, Nenquin M, Mathot F, Tamagawa $\mathrm{T}$ (1982) Diazoxide and D600 inhibition of insulin release. Distinct mechanisms explain the specificity for different stimuli. Diabetes 31: 776-783

41. Malaisse WJ, Sener A (1981) Calcium-antagonists and islets function. XII. Comparison between nifedipine and chemically related drugs. Biochem Pharmacol 30: 1039-1041

42. Ashcroft SJH, Ashcroft FM (1992) The sulfonylurea receptor. Biochim Biophys Acta 1175: 45-59

43. Inagaki N, Gonoi T, Clement IV JP et al. (1995) Reconstitution of IKATP: an inward rectifier subunit plus the sulfonylurea receptor. Science 270: 1166-1170

44. Nelson DA, Bryan J, Wechsler S, Clement IV JP, AguilarBryan L (1996) The high-affinity sufonylurea receptor: distribution, glycosylation, purification, and immunoprecipitation of two forms from endocrine and neuroendocrine cell lines. Biochemistry 35: 14793-14799

45. Loechner KJ, Kream RM, Dunlap K (1996) Calcium currents in a pituitary cell line (AtT-20): differential roles in stimulus-secretion coupling. Endocrinology 137: 1429-1437

46. Rasmussen H, Zawalich KC, Ganesan S, Calle R, Zawalich WS (1990) Physiology and pathophysiology of insulin secretion. Diabetes Care 13: 655-666

47. Zawalich WS (1996) Regulation of insulin secretion by phosphoinositide-specific phospholipase $\mathrm{C}$ and protein kinase C activation. Diabetes Rev 4: 160-176 